\title{
Attitudes and Purchase Behaviour of Green Products among Generation Y Consumers in South Africa
}

\author{
Muntaha Anvar, Miss \\ Marike Venter, Ms \\ University of the Witwatersrand \\ Muntaha.anvar@hotmail.com, Marike.Venter@wits.ac.za
}

Doi:10.5901/mjss.2014.v5n21p183

\begin{abstract}
The purpose of this study was to determine what factors influence attitudes and purchase behaviour of green products among Generation $Y$ consumers in South Africa. The factors that were under investigation in this study were social influence, environmental awareness and price. Further, this study aimed to investigate whether consumer attitudes can in fact influence consumers' purchase behaviour of green products. A quantitative approach was used for data gathering. Data collection was conducted by means of self-administered questionnaires among 200 students between the ages of 18 to 23 . The data was analysed by using statistical methods such as simple and multiple linear regressions. The results from the study indicated that social influence, environmental awareness and price, positively influence individuals' attitudes towards green products. The effect of attitude on buying behaviour was also positive; hence consumers with positive attitudes towards green products are more likely to purchase green products. Further, the findings indicated that there is indeed a difference between males and females with regards to buying behaviour of green. The findings of the study will provide marketers with a clearer understanding as to how they can influence Generation Y's attitude and buying behaviour towards green products. With the Generation Y cohort being of crucial importance to marketers, companies can drive sales and increase market share through appropriate marketing strategies. This is essential for a developing country such as South Africa, and among Generation $Y$ consumers whom will play an active role in the future global economy.
\end{abstract}

Keywords: attitudes, buying behaviour, generation Y, green products

\section{Introduction}

"What we are doing to the forests of the world is but a mirror reflection of what we are doing to ourselves and to one another." - Gandhi

Green marketing has come into effect as a result of environmental degradation caused by the abundance of natural resources. Even though green marketing is not a completely new phenomenon, the emergence of green consumerism and socially conscious consumers are strong indicators of the green movement (Menon, Chowdhury and Jankovich, 1999; Sivadas, 1997). Likewise, companies are slowly introducing green marketing into their business practices by reducing the impact of production, manufacture and energy usage on the environment (Grant, 2008). Moreover, companies are using green marketing as a means for creating a competitive advantage (Han, Hsu, and Sheu, 2010).

Despite the great amount of awareness and knowledge on green marketing, the market share of green products is still significantly small; only $4 \%$ of consumers buy into green products, although $40 \%$ of consumers say that they will buy green products (Bartels and Hoogendam, 2011; Young, Hwang, McDonald and Oates, 2010). Further research indicates that while consumers express their concern towards the environment, this does not necessarily translate into green purchases (Young et al., 2010; Roberts, 1996). This statement is supported by Hughner, McDonagh, Prothero, Shultz and Stanton (2007) who state that even though consumers have a favourable attitude towards green purchases; it does not guarantee the purchase of green products. Thus, there is a gap between consumers' Attitude and their Behaviour, which is referred to as the attitude-behaviour gap. Due to the attitude-behaviour gap, marketers face a challenging task to develop segmentation and targeting strategies for green products (D'Souza, Taghian and Khosla, 2007). As a result, it is critical to examine the factors that influence consumers' selection and decision process, such as the Attitudes that shape Behaviour (Baker and Ozaki, 2008).

The youth of today, labelled as the Generation Y cohort (individuals born between 1986 and 2005), is of significance importance to marketers as they represent the future of environmentalism (Markert, 2004; Eastman and Liu, 
2012). Gatersleben, Steg and Vlek (2002) propose that people who spend the most on organic and green products are the young and affluent class. Given that the African portion of this cohort makes up $84 \%$ of the South African market, they are an important target market for the green movement, and remains under researched, specifically concerning their Attitudes towards environmental issues (Lee, 2009; Statistics South Africa, 2011),

Therefore, the purpose of this paper is to determine what factors influence Attitudes and Purchase Behaviour of green products among Generation $\mathrm{Y}$ in South Africa. The findings contribute to the current slow development in the green sector (Borchers, Duke and Parsons, 2007), by providing an extensive theoretical understanding on the Attitudes and Behaviours towards green marketing of Generation Y. It provides marketers with a better understanding of Generation $Y$ consumers' Attitude towards and their Buying Behaviour of green products. It also gives marketers a clearer guide as to how the study of Attitudes and Behaviour can assist with the improvement of advertising efforts for green markets (Baker and Ozaki, 2008). The findings of the study will assist marketers to align their green marketing practices to better attract the young South African consumers and thus achieve a distinctive competitive advantage. Marketers need to encourage Generation $Y$ to buy green products as they are the future consumers with large spending power.

By means of a quantitative study, 200 questionnaires were distributed among university students to investigate their Attitude and Behaviour towards green products. Additionally, the influence of three factors on Attitude and Green Purchase Behaviour were explored, namely Social Influence, Environmental Awareness and Price. Further, Gender was used as a moderator and finally the relationship between consumer Attitudes and Buying Behaviour were explored.

\section{Theoretical Background}

Behaviour measured in studies has always been different from actual purchase behaviour (Gatersleben et al., 2002). Little is known about the relationship between the psychological variable of attitude and actual environmental impact because studies have not focused on environmental behaviour extensively (Gatersleben et al., 2002).

\subsection{An Overview of the Consumer Decision Making Process}

The Consumer Decision Making Process is a road map that allows marketers and managers understand consumers' minds helping them guide the marketing mix, promotions and other sales strategies (Byron, 2005). The environment has also had an impact on consumer behaviour (D'Souza et al., 2007). The decision making process is very complex in terms of green consumption (Young et al., 2010). In this era of wide-spread environmental concern, it is extremely important to analyse the influences and decision making involved in consumers purchases of environmentally safe goods and services (Oztek and Cengel, 2013).

\subsubsection{Involvement in Green Consumerism}

Environmental concern is valued more when consumers are buying everyday low involvement products (Young et al., 2010). Consumers believe that Green Products are expensive and they do not want to take high level of risks. In this instance purchasing high involvement products is more affected by social influences of friends and family (Bloch, Sherrell \& Ridgway, 1986).

The different stages of the Consumer Decision Making Process (CDP) model can be discussed in relation to consumers Green Purchase Behaviour. The first step involves the Need Recognition and Awareness of the Purchase Problem that is to be solved or the needs and wants that are to be fulfilled (Bloch et al., 1986). In terms of green consumption, more awareness at this stage will improve consumption choices favouring Green Purchase Behaviour (Bloch et al., 1986). Information Search in CDP can be external or internal (Byron, 2005). The information base for green consumption taken from internal search such as consumers feelings and past experiences is very low (Baker and Ozaki, 2008). To retrieve extended information on green products high external search activities are advised. Information search leads to the pre-purchase Evaluation of Alternatives where consumers compare and choose the one that best fulfils the need or solves the purchase problem (Byron, 2005). If the preferred product has been found leading to Purchase and consequently consumption, this step is referred to as the Green Purchase Behaviour. Finally the CDP ends as PostPurchase Evaluation explains the degree of satisfaction or dissatisfaction achieved after usage of the product or service (Byron, 2005). If consumers are fully satisfied this might results in an intention to repurchase or becoming loyal to the brand (Byron, 2005).

Besides the typical Consumer Decision Making Process green consumption and purchase behaviour can also be explained by Young et al.'s (2010) Green Consumer Purchasing Model shown in figure 1 below. This model also has 
green values or awareness as the beginning step leading to purchase. Values and Awareness are followed by the Search of Alternatives based on the green criteria that consumers have set where they might also confirm product knowledge through influences of friends, family or past experiences (Young et al., 2010).

Figure 1: Green Consumer Purchasing Model

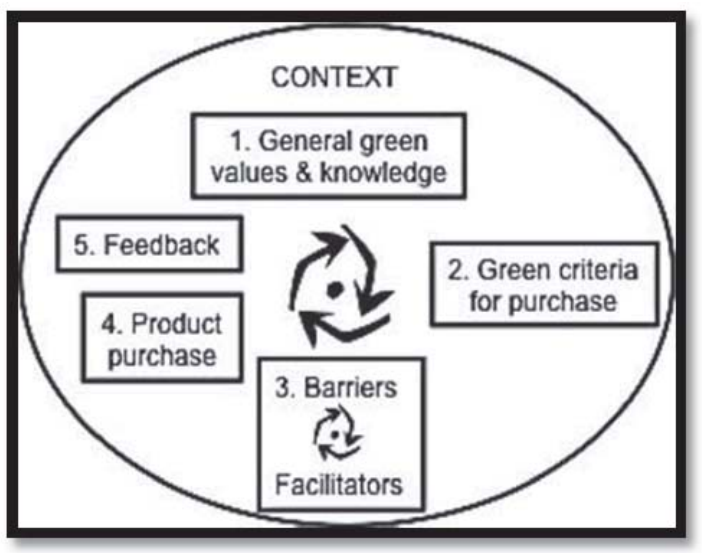

Source: Young et al. (2010)

\subsubsection{Attitudes and Purchase Behaviour of Green Products}

The correlation between Attitude and Behaviour can be explained by Fraj and Martinez (2007) two-component and threecomponent relationship model. This model illustrated that out of the three Affective, Cognitive and Conative components of Attitude, Affect plays the main role in predicting Environmental Attitude (Fraj and Martinez, 2007).

\subsubsection{Green Purchase Behaviour}

Behaviours in the context of the green movement are defined as direct actions that have an effect on the environment (Grob, 1995). Some common green practices include recycling, purchasing organic food, using less paper, saving electricity, avoiding aerosols and plastic bags (Gilg, Barr \& Ford, 2005). Consumers have realised the impact of their behaviour on the environment and are shifting towards green buying even agreeing to pay more for green products. Han et al., (2010) indicate a gradual increase in consumers' demand of green enterprises.

To analyse consumers' pro-environmental behaviour, psychographic characters such as knowledge, awareness, values, attitudes, perceptions and concerns for the environment are more reliable than demographics characters (Oliver, Volschenk \& Smit, 2011). Consumers who are extremely conscious ("true-blue" greens) might even sacrifice good quality preferences and accept lower levels of performance to save the environment (Han et al., 2010; Roberts, 1996). To better understand consumers green preferences and behaviours to develop green marketing and service strategies Han et al. (2010) and Luzar and Diagne (1999) use Ajzens Theory of Planned Behaviour (TPB) considering it as a strong predictor of human behaviour. The TPB has been derived from the Theory of Reasoned Action (TRA) which allows greater focus in examining the influence of social determinants on behaviour; where social factors are tested as part of the model in this study.

Companies have also introduced Green Product Innovations (GPI's) that perform better than the conventional green products to overcome the gap between economy and environment (Baker and Ozaki, 2008). The most common environmental behaviours people engage into include recycling of plastics, cans, bottles, newspapers and fertilising of garden waste (Baker and Ozaki, 2008). Central to understanding consumer behaviour is the fact that people like to evaluate costs and benefits resulting from a particular behaviour (Han et al., 2010). This can be an effective tool in determining the likelihood to perform any behaviour based on the positive or negative attitudes developed through the evaluations. Basically a positive attitude strengthens the intention and willingness to perform a specific behaviour (Han et al., 2010). 


\subsubsection{Attitude}

Attitudes are better predictors of pro-environmental behaviour than other variables (Padel and Foster, 2005; Tanner and Kast, 2003). Attitudes also inform behaviour (Young et al., 2010). Referring to Ajzens Theory of Planned Behaviour it is stated that consumers' beliefs also form attitudes which are translated into intention and behaviour (Baker and Ozaki, 2008). Consumers' thoughts and feelings influence behaviour (Baker and Ozaki, 2008). Hoyer and Maclnnis (2004) argue that attitudes need to be changed to turn behaviour toward environmental practices.

The two main types of attitudes, which many studies have addressed throughout history, regarding environmental behaviour are Importance (perceived importance where consumers express concerns or feel that the ecological issues are important to them) and Inconvenience (level of inconvenience that consumers face when adapting or behaving in an ecologically friendly manner) (Laroche, Bergeron and Barbaro-Forleo, 2001). According to Laroche et al. (2001) Perceived level of responsibility (where consumers believe that businesses are not playing their role in production of ecofriendly consumption products) is also an attitudinal variable that determines consumers' level of environmental consciousness.

Roberts (1996) also identifies selected attitudinal variables of ecologically conscious consumer behaviour. The first attitudinal correlate is Perceived Consumer Effectiveness which is an individual's judgement on his or her ability to have an impact on the environmental resource problems (Roberts, 1996). Liberalism was associated to democrats and liberals who were found to be more ecologically concerned than other groups of individuals (Roberts, 1996). Lastly, Environmental Concern is the concern of social responsibility (Robert, 1996).

Peattie (2001) explains consumer attitudes towards ecological behaviours through a simplified model of environmental orientation during the consumption process. The model shows that based on the degree of conscious environmental orientation, the attitudes of majority of the ecologists were consistent over the consumption process, see figure 2 (Peattie, 2001).

Figure 2: Model of Environmental Orientation

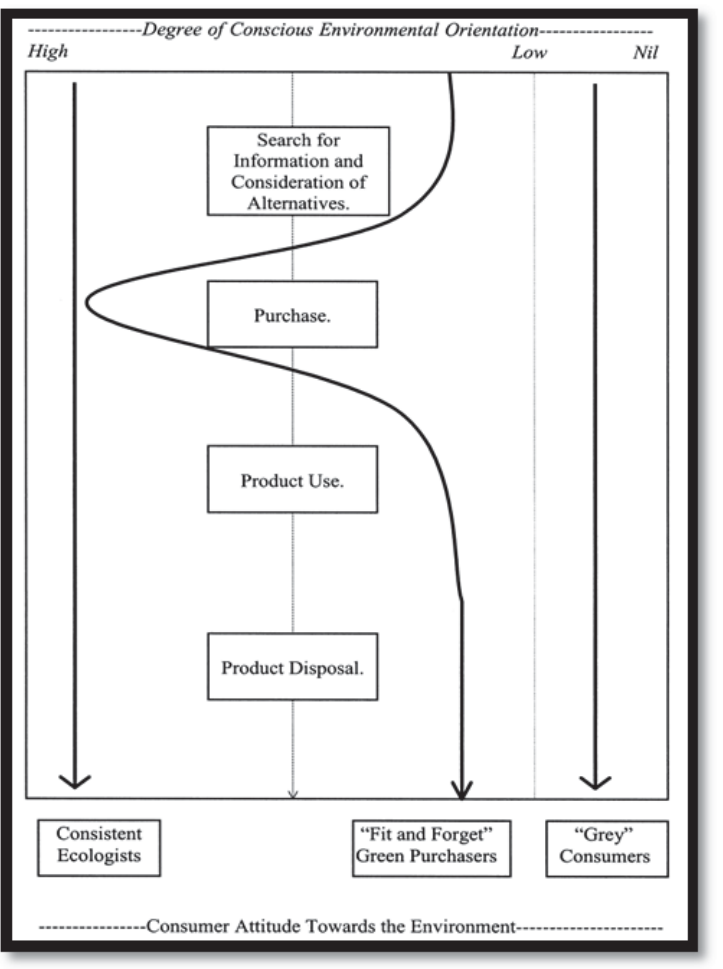

Source: Peattie (2001) 


\subsection{Factors influencing Attitudes and Purchase Behaviour of Green Products}

\subsubsection{Social Influence}

The value-action gap identifies a crucial point of influence where many consumers would be reactive due to the presence of others (Baker and Ozaki, 2008). For instance some people might throw rubbish in bins when other people are around them and would not do so otherwise. An individual can be highly influenced by his or her social surrounding including relatives, friends, colleagues and business partners. (Han et al., 2010). In mass media advertising reference groups have been rarely used in an association with green products, which is another reason for the niche green market and very few green products (Baker and Ozaki, 2008).

Ajzens Theory of Planned Behaviour (TPB) explains the factor of Subjective norms which are associated with social pressures to perform or not to perform a specific behaviour (Han et al., 2010). Han et al. (2010) also highlight the issue of referents where a consumer would act thinking whether their referent would approve or disapprove certain behaviour. Social influences have said to promote many recycling activities in young consumers specially (Baker and Ozaki, 2008). Young consumers are strongly affected by the coercive power of the group they belong to and are open to change more easily (Baker and Ozaki, 2008).

The model for this study has been adapted from the model proposed by Bartels and Hoogendam (2011) which also shows that Social influence of or direct identification with an environmentally conscious consumer has an impact on Green Purchase Behaviour. These are also known as spill-over effects on the main correlation (Baker and Ozaki, 2008).

Figure 3: Social Identification Model

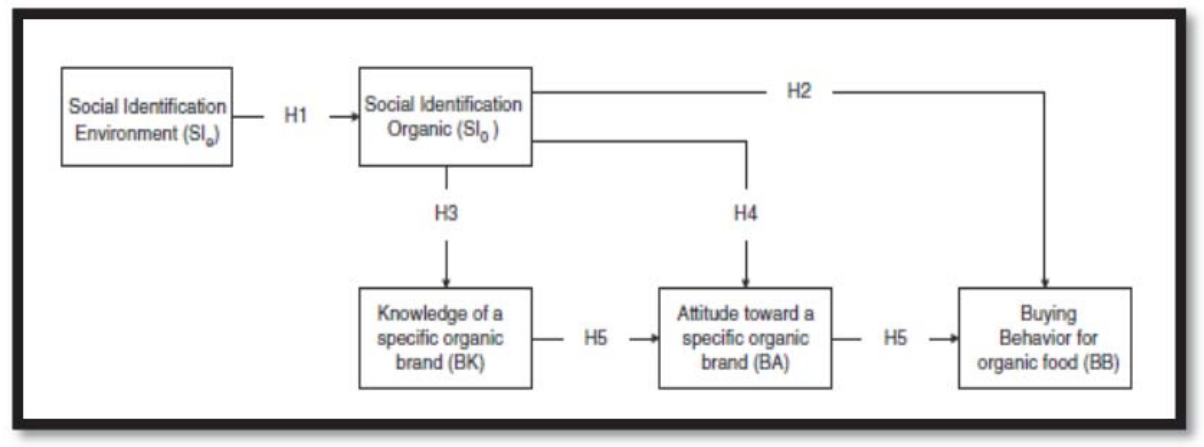

Source: Bartels and Hoogendam (2011)

Grob (1995) also says that differences in environmental attitudes and behaviours may occur as a result of social group memberships and associations. Bush, Martin and Clark (2001) expand on consumers socialisation process through the use of social learning theory which proved that direct role models such as fathers, mothers and teachers had the greatest impact on consumers market place knowledge and purchase decisions of consumers, especially the attitudes of young adults (Bush et al., 2001). Consumer socialisation is the process through which consumers gain knowledge, skills and form attitudes towards purchases in the marketplace (Bush et al., 2001). Celebrity role models or endorsers can also induce a social pressure but in the domain of materialistic, high status and expensive products. Such entertainers including athletes are also a good source of product information (Bush et al., 2001).

\subsubsection{Environmental Awareness}

For the past few years a growing interest has been noted in raising awareness about environmental issues among consumers when they are making purchases (Young et al., 2010). Environmental knowledge is linked to positive environmental behaviour (Tanner and Kast, 2003). Exposure is a key factor to environmentalism. The more knowledge people have about Green Behaviour practices the more they will act positively (Roberts, 1996).

Environmental awareness has been ranked as one of the most important predictors of appropriate environmental behaviour (Grob, 1995; Gatersleben et al., 2002). Environmental awareness is also considered as knowledge about the 
facts and general concepts relating to the environment and ecosystems (Mostafa, 2007). This knowledge is also known as Ecoliteracy (Laroche et al., 2001). Abstract knowledge influencing all the different phases of the decision making process is also considered important and essential in environmentally concerned behaviour (Laroche et al., 2001). Grob (1995) explains two main components of awareness which are factual knowledge and recognition of environmental problems for testing more appropriate eco-friendly behaviour. In this study the model of External Influences on Environmental Awareness by Gadenne et al. (2009) was also used to give an overview of the factors influencing environmental awareness.

There are a huge proportion of consumers who are unaware of the environmental consequences of their behaviour (Padel and Foster, 2005). This is because they are not enough exposed to the different communications created in terms of green products (Baker and Ozaki, 2008). However they desire more information on eco-friendly practices (Young et al., 2010). Many consumers cannot identify organic products due to their non-availability as well as the presence of very few brands available in some regions only (Gatersleben et al., 2002). It is also very important for consumers to have marketplace knowledge about green products such as prices, shopping locations and availability of products in stores (Bush et al., 2001).

\subsubsection{Price (Willingness to pay)}

Modifications in Green Purchase Behaviour must be investigated in the context of product attributes such as price. Consumers are price sensitive when it comes to going green (D'Souza et al., 2007). Young et al. (2010) identified price as a barrier to Green Purchase Behaviour by stating that it reduces the influence of green values and attitude in making purchase decisions. But consumers who are most involved with the environment are willing to pay a green premium in comparison to those who are less involved and not willing to pay more (Vlosky, Ozanne \& Fontenot, 1999).

Customer willingness to pay and price perceptions have been considered as two important factors when studying the construct of price in relation to attitude and behaviour (Oliver et al., 2011). The severity of harm caused by ecological issues to the environment also encourages consumers to pay higher price for certain green products (Laroche et al., 2001). The model of Attitude and Willingness to Pay by Hansla, Gamble, Juliusson and Garling (2008) is an appropriate model for understanding positive attitude and willingness to pay for electricity produced through green sources. Laroche et al. (2001) also look at the relationship between attitude and price and willingness of consumers to pay by explaining two significant attitudes namely the attitude of perceived inconvenience and the attitude of corporate responsibility.

Behaviours such as recycling and buying green did not predict willingness to pay more for green products and services. For instance a consumer might have a positive attitude towards recycling and recycles on a regular basis, but may not be willing to pay more (Hansla et al., 2008). However, committed environmentalists do not worry about price as a major factor in determining their behaviour (D'Souza et al., 2007). But price remains a barrier unless discounts and promotions are emphasised, quality and product performance are made credible and value for money is obtained (Gatersleben et al., 2002).

\subsubsection{Gender}

Studies that have not taken demographic profiles of green consumers into consideration, have failed to review environmentalism effectively (Roberts, 1996). The reason for such a discrepancy is that some people act more responsibly than others (Padel and Foster, 2005). Baker and Ozaki (2008) also consider Gender as an important demographic predictor of Attitude towards Green Purchase Behaviour.

Turner (1994) identifies a large difference in the attitudes of men and women. Roberts (1996) shows evidence that majority of the green consumers are females. Females always performed more ecologically than males (Gilg et al., 2005). Females with higher education have a greater positive Attitude towards Green Purchase Behaviour and environmental consciousness (Oztek and Cengel, 2013). Gilg et al. (2005) identified more males to be present in the group of nonenvironmentalists. Males are less environmentally active. But men in the UK are said to becoming increasingly health conscious (Gatersleben et al., 2002). Therefore a more comprehensive study on Attitudes of Genders is required due to the contradictory results stated above (Mostafa, 2007).

\subsection{Generation Y (The Millenials)}

According to Sullivan and Heitmeyer (2008) Generation Y are the group of consumers born between the years 1977 to 1994 and are aged between 14 to 31 years old. This group of consumers are characterised by the norms of high 
discretionary income, quality seekers, technologically advanced, socially conscious, and willing to pay more for brands and are brand loyal (Sullivan and Heitmeyer, 2008; Lee, 2008). Smith (2010) refers to Generation Y as the Millenials and states that little research has been done to study the environmental behaviour of Generation Y.

Borchers et al. (2007) from their study identified that the respondents aged below 30 preferred the alternative of green products rather than non-green products. D'Souza et al. (2007) also associated Green Purchase Behaviour with the demographic characteristics being young, affluent, well-educated and dwelling in urban areas. Statistically, most of the green consumers are young females (Gilg et al., 2005).

Generation $Y$ is highly aware of the impact of global warming and value green facilities from home to workplace (McDougle, Greenspan and Handy, 2011). Their attitudes towards the environment are positively related to their proenvironmental actions (Smith, 2010). As a result they are becoming highly active in the market place (Lee, 2008). Therefore this research was focused on testing the Attitudes of Generation $Y$ to develop motivations that encourage their Green Buying Behaviour in a South African context.

\section{Research Design and Methodology}

A quantitative method was applied through the use of self-administered survey questionnaires. A conclusive approach was applied where secondary data was collected in the form of journal articles from existing academic databases. Data gathering was pre-planned through descriptive research and the cause-and-effect relationships between variables were tested through the casual research technique (Malhotra and Birks, 2007). For descriptive research, a cross-sectional design was used.

\subsection{Primary Data and Sample}

Primary research was conducted by collecting information directly from respondents through questionnaires which were distributed to respondents from an independent sample of 200 students from the university's student population who were approached on different campuses as well as in class. This population consisted of male and female students, aged between 18 to 25 years (Generation Y) from the University of the Witwatersrand in Johannesburg, South Africa. Generation $Y$ is considered to be the biggest group of future buyers and said to have greater spending power than other consumers (Noble, Haytko and Phillips, 2009). Therefore, convenience sampling was used. Ethical issues were taken into consideration for this study as the responses collected from the participants through questionnaires were kept confidential.

\subsection{Secondary Data}

A comprehensive literature review was carried out to identify gaps in the literature. The two main reputable databases that were used are Google Scholar and the Wits library database including Emerald, EbscoHost, ScienceDirect, Wiley and JSTOR. A wide range of journal articles, dissertations and working papers from both national and international researches were used to maintain the quality of the study.

\subsection{Data Processing}

From here a step by step processing of the data took place through collecting, editing and coding it based on the format of the questionnaire. All the data was stored in excel spreadsheets so that it could be imported on to SAS Software Enterprise Guide 5 for testing and analysis.

\subsection{Measuring Instrument}

The statements or items in the questionnaire were adapted from various studies of previous literature with pre tested, reliable and valid scales. These scales were modified to suit this study and are individually listed below for each construct.

\section{- Social Influence Scale}

The items for social influence were adapted from: Han et al's. (2010) 7-point Normative Beliefs and Subjective Norms Scale.

One of the items was take from Bush et al's. (2001) Role Model Influence likert type scale. 


\section{- Environmental Awareness Scale}

The items for this scale were adapted from:

Mostafa's (2007) 7-point likert type Perceived Environmental Knowledge Scale.

Bush et al's. (2001) three item Marketplace Knowledge Scale.

\section{- Price Scale}

The items for the variable of price were mainly adapted from:

Laroche et al's. (2001) 9-point Consumers' Willingness to pay Scale.

Some of the items were modified and adapted from Han et al's. (2010) 7-point Control Beliefs Scale

Bush et al's. (2001) three item Marketplace Knowledge Scale.

Oliver et al's. (2011) propositions of Free Rider problems.

\section{- Attitudes towards Green Products Scale}

Attitudes about green products were measured from a number of scales including:

Laroche et al's. (2001) 9-point likert type attitudes scale

Mostafa's (2007) three-item 5-point likert type green purchase attitudes scale

Oliver et al's. (2011) attitude and beliefs propositions

Grob's (1995) six-item 7-point likert type scale of recognition of environmental problems and negative emotional reactions.

\section{- Green Purchase Behaviour Scale}

Green purchase behaviour consisted of a scale of items adapted from:

Laroche et al's. (2001) 9-point likert type behaviours scale.

Han et al's. (2010) seven-point behavioural beliefs, visit intention and environmental friendly activities scales. Mohr and Webb's (2005) 26-item 5-point response scale of socially responsible purchase and disposal.

Initially, a pilot study was done that consisted of a sample of 20 respondents. A cronbach alpha and principle component analysis confirmed the reliability and validity of the research instrument. This waas followed by the reverse coding of the negative statements. In this study 194 of the 200 questionnaires were completed and usable for analysis.

\subsection{Data Analysis}

A simple linear regression was used to test the relationships between different variables. social influence, environmental awareness and price were the independent variables. The dependent variables were and attitude towards green products and green purchase behaviour. Gender served as the moderating variable to test for the interaction between attitude and purchase behaviour. Hypotheses $\mathrm{H}_{1}$ to $\mathrm{H}_{3}$ tested the relationship between each indivudal influencing variable (social, influence, environmental awareness and price) and attitude. $\mathrm{H}_{4}$ tested the interaction of gender on the attitude-behaviour relationship, whereas $\mathrm{H}_{5}$ tested this relationship. These tests were conducted by means of a simple linear regression analysis. $\mathrm{H}_{6}$ tested the combined relationship between the three influecing variables and Attitude through simple linear regression. These proposed hypotheses were as follows:

$\mathrm{H}_{1}$ : There is a relationship between social influence and attitude of green products among generation $Y$ consumers.

$\mathrm{H}_{2}$ : There is a relationship between environmental awareness and attitude of green products among generation $Y$ consumers.

$\mathrm{H}_{3}$ : There is a relationship between price and attitude of green products among generation $\mathrm{Y}$ consumers.

$\mathrm{H}_{4}$ : The interaction of gender does have an influence on the relationship between attitude and green purchase behaviour among generation $Y$ consumers.

$\mathrm{H}_{5}$ : There is a relationship between attitude and green purchase behaviour among generation $Y$ consumers.

$\mathrm{H}_{6}$ : There is a relationship between social influence, environmental awareness and price and attitude among generation $Y$ consumers.

\subsection{Confidence Levels}

The confidence level used for this study was $95 \%$, thus using an alpha value of 0.05 . 


\section{Research Results}

This section presents the data analyses and the empirical results obtained from statistically testing the data.

\subsection{Descriptive Statistics}

Descriptive statistics were also used to compare and analyse the responses in terms of respondent demographics. The first demographic characteristic analysed here was age where majority of the respondents were aged among 18 to 25 representing the age of the sample selected for the study. Looking at the demographic factor of gender, majority (65\%) of the respondents were females with a total of 126 out of 194 in comparison to 69 male respondents. Also majority of the respondents belonged to the Faculty of Commerce, Law and Management. Descriptivm analysis tests that were used to determine the mean responses for all the study variables to track consumers' agreement or disagreement. The mean values from descriptive statistics showed that for all the variables except price, the values were between 3 (Neutral) and 4 (Agree) on the response scale.

Table 1: Summary Statistics - Mean Responses for Variables

\begin{tabular}{|c|l|c|}
\hline No. & Analysis Variable & Mean of Responses \\
\hline 1 & Social Influence & 3.08 \\
\hline 2 & Environmental Awareness & 3.24 \\
\hline 3 & Price & 2.83 \\
\hline 4 & Attitude & 3.90 \\
\hline 5 & Green Purchase Behaviour & 3.63 \\
\hline
\end{tabular}

\subsection{Simple and Multiple Linear Regression Analysis}

All the hypotheses proposed for the purpose of the study $(\mathrm{H} 1-\mathrm{H} 6)$ were supported with $\mathrm{p}$-values of less than 0.01.This proved that there was a relationship between social influence, environmental awareness, price and attitude, individually as well as collectively. Also, there was a relationship between green purchase behaviour and attitude. The interaction of gender also had a positive impact on the correlation between attitude and green purchase behaviour. This showed that all the tested relationships were significant.

\subsection{Outlier Diagnostics}

A test for the outlier diagnostics was conducted to check for data points (responses) that were different from others and had possibly affected the regression results. Various statistics were used to calculate the outliers range such as the residual statistic, RStudent statistic, Hat Diagonal (Leverage) statistic, COVRATIO statistic, DFFITS statistic and DFBETAS statistic. Once the statistic ranges were calculated, values were analysed through conditional formatting on excel to see if they all lied within the statistic range. Fourteen outliers were detected outside the range and removed from the study. The regression analyses were ran once again for all the relationships to see if the outliers had major effects. The values of R-Square and Coefficient Variance were checked to see if the absence of outliers improved the data results or not. The effects of removing outliers improved the results for the Linear Regression between social influence and attitude, environmental awareness and attitude, the interaction of gender and the multiple regression between social influence, environmental awareness, price and attitude. The new results for the tests were noted down. For the linear regressions between price and attitude and attitude and green purchase behaviour, the effect of outliers did not improve the results. Hence the original data results were retained for them.

\subsection{Transformations}

Once the outlier diagnostics were considered, the residual plots for all the regressions were carefully aalysed to check the effects of removing outliers and improve the data further if there were any irregularities. In this case transformations of the data should be carried out. Transformations are also used to check for straight line relation in a Regression (Galpin and Krommenhoek, 2013). The data was transformed by means of a square root and log transformations and regression analysis were conducted again to check for the improvements in results. Similar to outlier diagnostics the values of R- 
square and coefficient variance were analysed. These were compared to the values obtained in outlier diagnostics to check if the values increased or decreased. Transformation of the data showed improved results for the model for the linear regressions between social influence and attitude, price and attitude, the interaction of gender, attitude and green purchase behaviour and the multiple linear regression between social influence, environmental awareness, price and attitude. The only regression result that did not show any improvement after transformation was for the linear regression between environmental awareness and attitude.

\subsection{Hypotheses Testing after Outlier Diagnostics and Transformations}

The $p$-values obtained for all the regressions after re-analyses were significant $(P=0.0001)$. According to results all the hypotheses $\left(\mathrm{H}_{1}\right.$ to $\left.\mathrm{H}_{6}\right)$ were be significant with positive relationships between all the variables.

\subsection{Pearson Correlation Coefficient Testing}

Pearson's correlation coefficients were used to determine the strength of relationships between the variables. Results indicated that none of the values were close to +1 or -1 but were positive (social influence and attitude -0.39 or $39 \%$, environmental awareness and attitude -0.48 or $48 \%$, price and attitude -0.34 or $34 \%$, attitude and green purchase behaviour -0.76 or $76 \%$ ). It can be concluded that the strength of all the correlations between the variables were positive but very low in terms of achieving a significant level of correlation statistically.

\section{Discussion and Conclusion}

The findings indicated that all three factors, namely social influence $(\mathrm{H} 1)$, environmental awareness $(\mathrm{H} 2)$ and price $(\mathrm{H} 3)$ influenced consumer's attitude towards green products. This suggested support for the findings proposed by Han et al. (2010) and Grob (1995), Mostafa (2007) and Bush et al. (2001). Further, Oliver et al. (2011) and Laroche et al. (2001) respectively stated that social influence, environmental awareness and price influence attitudes towards green products. These findings posed several implications for marketers. Firstly, marketers can target their green marketing campaigns at friends and family in an attempt to influence the attitudes of Generation $Y$ consumers (to utilize social influence). Secondly, marketers need to create awareness in order to influence attitudes. This can be done through awareness implemented in their IMC plans. The third factor, price, provides marketers with the opportunity to implement more affordable pricing strategies for green products, due to the sensitivity of consumers towards the high prices often associated with green products. Support for the fourth hypothesis was found indicating a significant difference between gender and both attitude and buying behaviour. Mostafa (2007) and Gatersleben et al. (2002) propose that males and females differ in their attitude and behaviour towards green products. Males tend to be less environmentally friendly than females. Therefore marketers targeting strategies should be improved to increase their purchase performance. Since males are less environmentally conscious consumers therefore an extra effort should be made into influencing the attitudes of males

The relationship between attitude and behaviour (H5) indicated positive results, which explains that the more positive an individual's attitude towards green products, the more likely that they will buy green products. Marketers should therefore consider individual needs and expectations and motivate consumers to create a positive attitude which will result in green purchase behaviour. This finding is consistent with previous literature (Grob, 1995; Gatersleben et al., 2002; Padel and Foster, 2005; Han et al., 2010).

\section{Contribution}

This study contributes both to theory and practice. Theoretically, this paper contributes to the fields of consumer behaviour and green marketing. It adds to current literature on predictors and motivators of green buying behaviour among the Generation Y consumers in Johannesburg. Secondly, it provides marketers with a clearer understanding as to how they can influence Generation Y's attitude and buying behaviour towards green products. More specifically, how marketing strategies could be tailored to utilise Social Influence, environmental awareness and price in order to accommodate for this market. With the Generation $Y$ cohort being of crucial importance to marketers, companies can drive sales and increase market share through appropriate marketing strategies. 


\section{Limitations}

Besides the contribution that this paper poses, there are several limitations. Firstly, this study has been conducted by using responses from a single sample of university students in South Africa and the results might not be as accurate to be generalised for Generation $Y$ in a different context or region. Also there might be biases that could occur while students were answering the questionnaire, where their responses might have been influenced by their friends or other students on campus. Since convenience sampling was used, one possible bias would occur where equal number of students was not selected from each faculty and students were approached randomly, resulting in majority of them coming from one faculty. For this study only three external variables of social influence, environmental awareness and price influencing Attitude have been analysed. Several other factors can be tested. This study did not focus on a single product, which might have also influenced the findings.

\section{Conclusion and Recommendations for Future Research}

To conclude, among Generation Y consumers, social influence, environmental awareness and price influence both attitudes and purchase behaviour towards green products. Further, females are more likely to have a positive attitude and buying behaviour of green products. Future studies can explore the influence of other factors on attitude and buying behaviour among this cohort. Generation $Y$ consumers in other regions can be researched to broaden the scope of the study. Future studies could conduct this research in light of a specific product category.

\section{References}

Baker, J. P. \& Ozaki, R. (2008). Pro-environmental products: Marketing influence on consumer purchase decision, Journal of Consumer Marketing, 25(5): 281-293.

Bartels, J. \& Hoogendam, K. (2011). The role of social identity and attitudes toward sustainability brands in buying behaviours for organic products. Journal of Brand Management, 18(9): 697-708.

Bloch, P. H., Sherrell, D. L. \& Ridgway, N. M. (1986). Consumer Search: An Extended Framework. Journal of Consumer Research, 13(1): 119-126.

Borchers, A. M., Duke, J. M. \& Parsons, G. R. (2007). Does willingness to pay for green energy differ by source? Energy Policy, 35: 3327-3334.

Bush, A. J., Martin, C. A. \& Clark, P. W. (2001). The Effect of Role Model Influence on Adolescents' Materialism and Marketplace Knowledge. Journal of Marketing Theory and Practice, 9(4): 27-36.

Byron, E. (2005). New Penny Chain Goes For 'Missing Middle'. The Wall Street Journal, (February): 68-97.

D'Souza, C., Taghian, M. \& Khosla, R. (2007). Examination of environmental beliefs and its impact on the influence of price, quality and demographic characteristics with respect to green purchase intention. Journal of Targeting, Measurement and Analysis for Marketing, 15(2): 69-78.

Eastman, J.K. \& Liu, J. (2012). The impact of generational cohorts on status consumption: an exploratory look at generational cohort and demographics on status consumption, Journal of Consumer Marketing, 29(2): 93-102.

Fraj, E. \& Martinez, E. (2007). Ecological consumer behaviour: an empirical analysis. International Journal of Consumer Studies, 31: 2633.

Gadenne, D. L., Kennedy, J. \& McKeiver, C. (2009). An Empirical Study of Environmental Awareness and Practices in SMEs. Journal of Business Ethics, 84: 45-63.

Galpin, J. S. \& Krommenhoek, R. E. (2013). Course Notes for Statistical Research Design and Analysis. School of Statistics and Actuarial Science, University of the Witwatersrand, Johannesburg, SA.

Gatersleben, B., Steg, L. \& Vlek, C. (2002). Measurement and Determinants of Environmentally Significant Consumer Behavior. Environment and Behavior, 34(3): 335-362.

Gilg, A., Barr, S. \& Ford, N. (2005). Green consumption or sustainable lifestyles? Identifying the sustainable consumer. Futures, 37 : 481-504.

Grant, J. (2008). Green Marketing. Strategic Direction, 24(6): 25-27.

Grob, A. (1995). A Structural Model Of Environmental Attitudes And Behaviour. Journal of Environmental Psychology, 15: $209-220$.

Han, H., Hsu, L. \& Sheu, C. (2010). Application of the Theory of Planned Behavior to green hotel choice: Testing the effect of environmental friendly activities. Tourism Management, 31: 325-334.

Hansla, A., Gamble, A., Juliusson, A. \& Garling, T. (2008). Psychological determinants of attitude towards and willingness to pay for green electricity. Energy Policy, 36: 768-774.

Hoyer, W. \& Maclnnis, D. (2004). Consumer Behavior, Houghton Mifflin, Boston, MA.

Hughner, R. S., McDonagh, P., Andrea, P., Shultz, C. J. \& Stanton, J., (2007). Who are organic food consumers? A compilation and review of why people purchase organic food, Journal of Consumer Behaviour, 6(2-3): 94-110.

Laroche, M., Bergeron, J. \& Barbaro-Forleo, G. (2001). Targeting consumers who are willing to pay more for environmentally friendly 
products. Journal of Consumer Marketing, 18(6): 503-520.

Lee, K. (2009). Gender differences in Hong Kong adolescent consumer's green purchasing behavior, Journal of Consumer Marketing, 26(2): 87-96.

Luzar, E. J. \& Diagne, A. (1999). Participation in the next generation of agriculture conservation programs: the role of environmental attitudes. Journal of Socio-Economics, 28: 335-349.

Malhotra, N. K., \& Birks, D. F. (2007). Marketing Research: an applied approach (3rd ed.). London, UK: Prentice Hall.

Markert, J. (2004). Demographics of age: generational and cohort confusion, Journal of Current Issues and Research in Advertising, 26(2): 11-25.

McDougle, L. M., Greenspan, I. \& Handy, F. (2011). Generation green: understanding the motivations and mechanisms influencing young adults' environmental volunteering. International Journal of Non-profit and Voluntary Sector Marketing, 16, 325-341.

Menon, A., Menon, A., Chowdhury, J. \& Jankovich, J. (1999). Evolving paradigm for environmental sensitivity in marketing programs: A synthesis of theory and practice. Journal of Marketing, (Spring): 1-15.

Mohr, L. A. \& Webb, D. J. (2005). The Effects of Corporate Social Responsibility and Price on Consumer Responses. The Journal of Consumer Affairs, 39(1): 121-147.

Mostafa, M. M. (2007). Gender differences in Egyptian consumers' green purchase behaviour: the effects of environmental knowledge, concern and attitude. International Journal of Consumer Studies, 31: 220-229.

Noble, S. M., Haytko, D. L. \& Phillips, J. (2009). What drives college-age Generation Y consumers? Journal of Business Research, 62: 617-628.

Oliver, H., Volschenk, J. \& Smit, E. (2011). Residential consumers in the Cape Peninsula's willingness to pay for premium priced green electricity. Energy Policy, 39: 544-550.

Oztek, M. Y. \& Cengel, O. (2013. )The Formation of Green Buying Strategy on the Scope of Consumer Decision Making Behavior. Online Academic Journal of Information Technology, 4(12): 7-17.

Padel, S. \& Foster, C. (2005). Exploring the gap between attitudes and behaviour: Understanding why consumers buy or do not buy organic food. British Food Journal, 107(8): 606-625.

Peattie, K. (2001). Golden Goose Or Wild Goose? The Hunt For The Green Consumer. Business Strategy and the Environment, 10: 187-199.

Roberts, J. A. (1996). Green Consumers in the 1990s: Profile and Implications for Advertising. Journal of Business Research, 36: $217-$ 231.

Sivadas, E. (1997)A preliminary examination of the continuing significance of social class to marketing: A geodemographic replication. Journal of Consumer Marketing, 14(6): 463-479.

Smith, K. T. (2010). An examination of marketing techniques that influence Millennials' perceptions of whether a product is environmentally friendly. Journal of Strategic Marketing, 18(6): 437-450.

Statistics South Africa. (2011). Mid-year population estimates: 2011. Key indicators, Statistical release P0302. [Online] Available:

http://www.statssa.gov.za (16 January 2012).

Sullivan, P. \& Heitmeyer, J. (2008.) Looking at Gen Y shopping preferences and intentions: exploring the role of experience and apparel involvement. International Journal of Consumer Studies, 32: 285-295.

Tanner, C. \& Kast, S. W. (2003). Promoting Sustainable Consumption: Determinants of Green Purchases by Swiss Consumers. Psychology \& Marketing, 20(10): 883-902.

Turner, J. C., Oakes, P. J., Haslam, S. A. \& McGarty, C. (1994). Self and Collective: Cognition and Social Context. Personality and Social Psychology Bulletin, 20(5): 454-463.

Vlosky, R. P., Ozanne, L. K. \& Fontenot, R. J. (1999). A conceptual model of US consumer willingness-to-pay for environmentally certified wood products. Journal of Consumer Marketing, 16(2): 122-136.

Young, W., Hwang, K., McDonald, S. \& Oates, C. J. (2010). Sustainable Consumption: Green Consumer Behaviour when Purchasing Products. Sustainable Development, 18: 20-31. 